\title{
Not so novel ecosystems
}

\author{
Steven N. Handel
}

$\mathrm{R}$ estoration ecologists face a phalanx of environmental enemies. Shoulder to shoulder are invasive species, habitat fragmentation, rampant urbanization, and that big hot gorilla in the room, climate change. All challenge our daily work and our long-term habitat targets. So many changes have occurred in the last decades that ecological theorists have begun a sizable literature on "novel ecosystems," habitats around us that have had no historical predecessors. These novel ecosystems may function quite differently from long-standing assemblages of species that we are accustomed to, like some well-worn family loveseat, and whose evolutionary history reflects long-term selective pressures.

The rampant changes pushed quickly forward by human actions have surrounded us with oddball communities different even from the habitats many of us studied in college. As new species move into landscapes both species richness and equitability can rapidly change. Different species have different dispersal rates and move across the land different ways. This phenomenon has long been studied as part of island biogeography theory where community "disharmony" is a regular feature of oceanic islands. Islands differ in many ways from nearby mainlands because of idiosyncratic dispersal rates of successful colonists, and ecological functions on island as well as community descriptions can be quite different from the mainland scene. Certain interspecific functions are sundered which drives, over time, ecological novelty of many island biotas (from the drosophilids of Hawaii to the great finch diversity of the Galapagos).

The concern about new species mixtures is more than an academic curiosity. There are enormous agricultural concerns now that new pathogens and pasts will infect our food production fields as the shuffled biological order moves too fast for either evolutionary responses or the horticultural ability to develop new resistant strains. This is more than food for thought; this is a challenge to our food.

Modification of the species mix within our habitats has also been documented in detail by paleobiologists. Over thousands of years, as glacial periods advanced and retreated, there is much evidence that even major tree

Ecological Restoration Vol. 33, No. 3, 2015

ISSN 1522-4740 E-ISSN 1543-4079

(O2015 by the Board of Regents of the University of Wisconsin System. species re-colonize newly available land at different rates. Recent forest structures of the 19th and 20th century are quite different from those of thousands of years ago. Plant species formations we think of as "normal" do not have a long history. From this perspective constant change in richness and equitability is not novel but is the pattern over millennia.

Some natural changes to biota not fomented by human activity also can occur at rapid rates. For example, the expansion of cattle egrets into the Americas started in the 1930s, after the first colonists were blown across the Atlantic from Africa. This one species is now common through much of the Western Hemisphere. What we define as natural communities and are in classic textbooks of northern hemisphere habitats (e.g., Braun, Whittaker, Braun-Blanquet) are snapshots of only the recent past. These are misleading snapshots as they show a kind of bio-stasis, not the dynamic system which keeps pulsing across the millennia.

We are interpreting recent changes, "novel ecosystems," as not a new ecological phenomenon that is modifying our habitats but rather a speeding up of ecological processes that have been present over many millennia. Our current biotic world reminds us of those centrifuges that spin too fast, and instead of sorting chemical species, end up as broken systems that function no more. Our human activities make us organic centrifuges that are moving so fast we are separating living species into zones that may function no more.

What is novel is pace, not process.

\section{Recommended References}

Davis, M.B. 1983. Quaternary history of deciduous forests of eastern North America and Europe. Annals of the Missouri Botanical Garden, 550-563.

Davis, M.B. and C. Zabinski. 1992. Changes in geographical range resulting from greenhouse warming: effects on biodiversity in forests. Global warming and biological diversity, 297-308.

Del Tredici, P. 2014. The flora of the future. Pages 238-257 in Projective Ecologies, C. Reed and N-M. Lister (eds). New York., NY: Actar.

Foster, D.R. and J.D. Aber. 2004. Forest in Time: the Environmental Consequences of 1,000 Years of Change in New England. New Haven, CT: Yale University Press.

Hobbs, R.J., E.S. Higgs and C. Hall. 2013. Novel Ecosystems: Intervening in the New Ecological World Order. John Wiley \& Sons. 
Hobbs, R.J., S. Arico, J. Aronson, J.S. Baron, P. Bridgewater, V.A. Cramer, P.R. Epstein, J.J. Ewel, C.A. Klink, A.E. Lugo, D. Norton, D. Ojima, D.M. Richardson, E.W. Sanderson, F. Valladares, M. Vilà, R. Zamora and M. Zobel. 2006. Novel ecosystems: theoretical and management aspects of the new ecological world order. Global Ecology and Biogeography 15: 1-7.

Kowarik, I. 2011. Novel urban ecosystems, biodiversity, and conservation. Environmental Pollution 159: 1974-1983.

Perring, M.P., R.J. Standish and R.J. Hobbs. 2013. Incorporating novelty and novel ecosystems into restoration planning and practice in the 21st century. Ecological Processes 2: 1-8.
Turner, R.M. 2003. The Changing Mile Revisited: an Ecological Study of Vegetation Change with Time in the Lower Mile of an arid and Semiarid Region. Tucson, AZ: University of Arizona Press.

Williams, J.W. and S.T. Jackson. 2007. Novel climates, no-analog communities, and ecological surprises. Frontiers in Ecology and the Environment 5: 475-482.

Williams, J.W., S.T. Jackson and J.E. Kutzbach. 2007. Projected distributions of novel and disappearing climates by 2100 AD. Proceedings of the National Academy of Sciences, 104: 5738-5742.

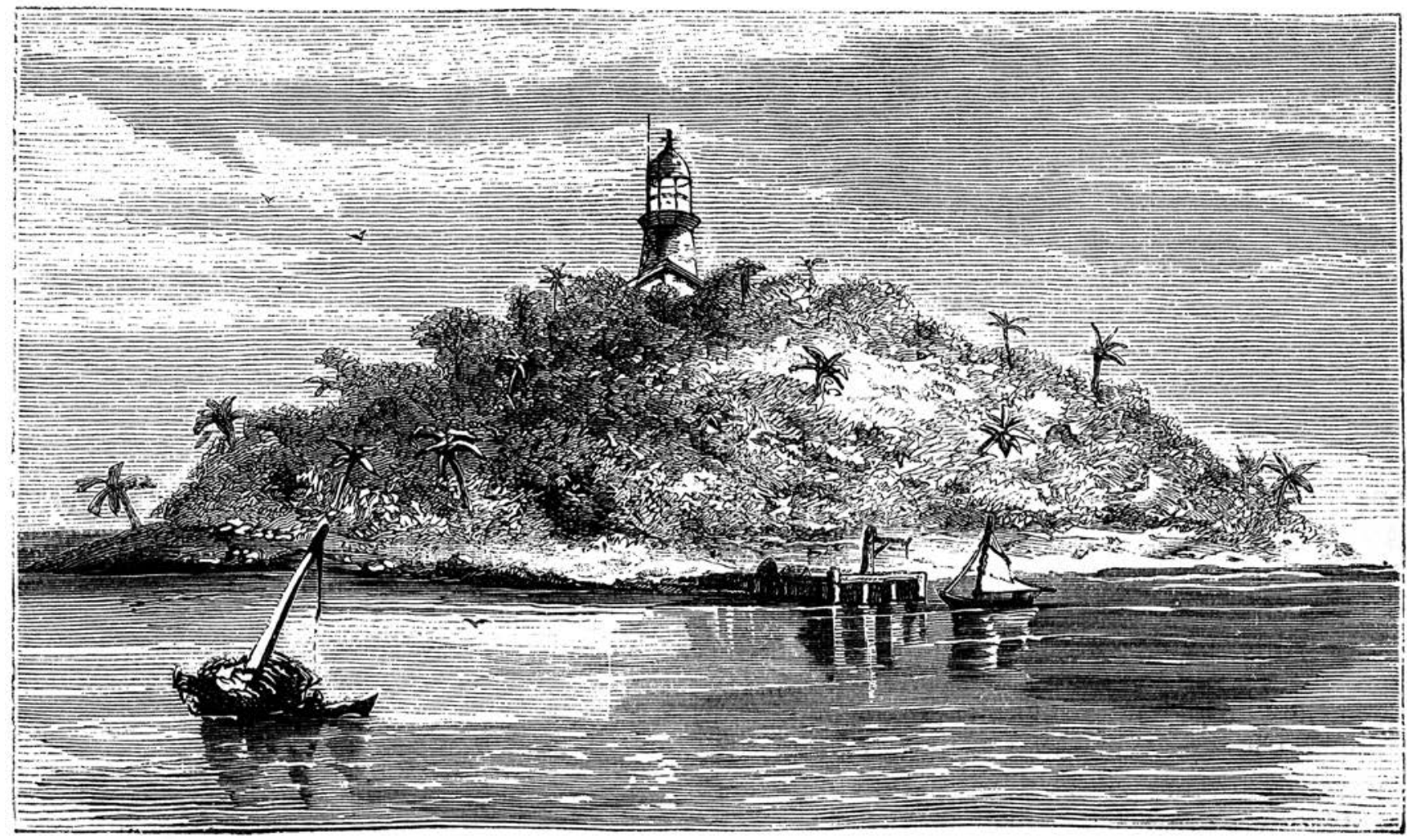

Lighthouse. 1871. Harper's New Monthly Magazine. New York, NY: Harper \& Brothers. The Florida Center for Instructional Technology, fcit.usf.edu. 